Paulina Fronczak-Chruściel

Uniwersytet Łódzki

iD ORCID ID: 0000-0002-6096-4464
OBLICZA WOJNY

TOM $3 \cdot$ MIASTO I WOJNA

ŁóDŹ2021 •ISBN 978-83-8220-556-5 • s.295-309

https://doi.org/10.18778/8220-556-5.16

\title{
UPADEK BERLINA OCZAMI KOBIET PRZYPADEK MARGRET BOVERI I URSULI VON KARDORFF
}

\begin{abstract}
Streszczenie. Celem artykułu jest ukazanie sytuacji w Berlinie w ostatnich miesiącach wojny z perspektywy dwóch dziennikarek - Margret Boveri oraz Ursuli von Kardorff. Analiza porównawcza dwóch źródeł ma na celu przedstawienie różnorodnych problemów, z którymi borykać się musieli mieszkańcy stolicy Trzeciej Rzeszy w końcowej fazie wojny - zaliczyć do nich można m.in. problemy $z$ aprowizacją, braki w dostawie prądu i wody czy utrudnienia w korzystaniu z komunikacji miejskiej. W kontekście powyższych rozważań nie mniej ważne były opisy paniki obywateli Niemiec spowodowanej zarówno licznymi bombardowaniami, jak i zbliżającymi się oddziałami Armii Czerwonej. Właściwe rozważania poprzedzone zostały krótką charakterystyką obu autorek, z uwzględnieniem m.in. takich aspektów jak pochodzenie, wykształcenie, ścieżka kariery czy podejście do polityki. Analiza tych informacji pozwoli zrozumieć nastawienie obu kobiet nie tylko do sytuacji w Berlinie, ale także do szeroko pojętych działań wojennych. W celu usystematyzowania narracji w artykule znalazł się także krótki opis sytuacji na obu frontach w ostatnich miesiącach wojny.
\end{abstract}

Słowa kluczowe: kobieta, Berlin, dziennikarka, Trzecia Rzesza, Il wojna światowa, dzienniki

Niniejszy artykuł ma na celu przedstawienie sytuacji w Berlinie w ostatnich miesiącach istnienia Trzeciej Rzeszy z perspektywy dwóch dziennikarek - Margret Boveri (1900-1975) oraz Ursuli von Kardorff (1911-1988). Zagadnienie końcowego etapu wojny jest wprawdzie od lat poruszane przez badaczy, wiele opracowań na temat tego okresu opartych jest w pewnym stopniu na relacjach kobiet, niemniej nadal rzadkością są analizy porównawcze materiałów źródłowych spisanych przez mieszkanki Niemiec. Problemem w zrozumieniu tego zagadnienia może być także stosunkowo nieliczna liczba źródeł przetłumaczonych na język polski. Za jeden z wyjątków może uchodzić anonimowa relacja 
wydana pod tytułem Kobieta w Berlinie. Zapiski z 1945 roku1, która zawiera opis ostatnich tygodni poprzedzających kapitulację Trzeciej Rzeszy oraz sytuacji krótko po jej podpisaniu.

Bazę źródłową niniejszego artykułu stanowią dziennik Ursuli von Kardorff, wydany w Polsce w 1992 r. pod tytułem Może to po raz ostatni ${ }^{2}$, a także wspomnienia Margret Boveri, spisane $\mathrm{w}$ formie listów i nieprzetłumaczone dotychczas na język polski, wydane w 1968 r. pod tytułem: Tage des Überlebens. Berlin $1945^{3}$. Biorąc pod uwagę specyfikę źródeł, informacje w nich podane, w miarę możliwości, weryfikowane były z powszechnie dostępnymi informacjami na temat ostatnich miesięcy istnienia Trzeciej Rzeszy, a także z opracowaniami poświęconymi zagadnieniu II wojny światowej ${ }^{4}$.

$\mathrm{Na}$ podstawie analizy materiałów źródłowych można zauważyć, że relacje von Kardorff oraz Boveri na temat życia w ogarniętej wojną stolicy pokrywają się tylko częściowo. Pierwsza z nich spędziła w Berlinie znacznie więcej czasu, jednak opuściła miasto w połowie lutego $1945 \mathrm{r}$. Z tego powodu narracja dotycząca sytuacji w stolicy oparta jest głównie na przekazach z drugiej ręki. W przypadku drugiej kobiety, relacja rozpoczyna się z początkiem lutego, ale znajdują się w niej także opisy wydarzeń z późniejszych miesięcy. $Z$ tego powodu analiza porównawcza obejmować będzie okres około dwóch tygodni, w pozostałych przypadkach będzie ona jednostronna. Cezura artykułu obejmuje wydarzenia od początku stycznia do 30 kwietnia $1945 \mathrm{r}$.

Artykuł składa się z czterech części. Na wstępie krótko scharakteryzowane zostały sylwetki dziennikarek, w części tej uwzględniono takie informacje jak pochodzenie, zdobyte wykształcenie oraz doświadczenie zawodowe, a także stosunek do polityki i okoliczności pobytu w Berlinie w ostatnich miesiącach wojny. Następnie omówiono sytuację na froncie od początku 1945 r., z uwzględnieniem nastrojów panujących w Niemczech. Właściwa część artykułu obejmuje przedstawienie relacji kobiet na temat życia w stolicy. Punkt ciężkości został położony w szczególności na problemy społeczne - utrudnienia związane ze zniszczeniami przez bombardowania, kłopoty z aprowizacją, a także,

\footnotetext{
${ }^{1}$ AnOnyma, Kobieta w Berlinie. Zapiski z 1945 roku, Warszawa 2009.

2 U. vON KARDORFF, Może to po raz ostatni, Warszawa 1992.

3 M. Boveri, Tage des Überlebens. Berlin 1945, München 1968.

${ }^{4}$ Przykładami takich opracowań są m.in. A. BeEvor, Berlin. Upadek 1945, Warszawa 2002; R.J. Evans, Wojna Trzeciej Rzeszy, Oświęcim 2017; F.G. FrITZ, Ostkrieg. Front wschodni. Wojna na wyniszczenie, Oświęcim 2018; T. THACKER, Koniec Trzeciej Rzeszy, Warszawa 2010.
} 
na ile to możliwe, ukazanie stosunków między obywatelami w chwilach kryzysu. Ostatnia część zawiera podsumowanie oraz wnioski powstałe po analizie materiału źródłowego. Analiza obu źródeł nie wyczerpuje wprawdzie tematu sytuacji kobiet w upadającej stolicy Trzeciej Rzeszy, stanowi jednak przyczynek do dalszych rozważań.

\section{Sylwetki dziennikarek}

Mimo wykonywania tego samego zawodu, losy obu kobiet oraz ścieżki ich karier znacznie się różniły. Różnice można odnaleźć nie tylko w przypadku pochodzenia, zdobytego wykształcenia czy motywacji do podjęcia pracy, ale także w ilości zachowanych źródeł i opracowań na temat ich postaci. Ursula von Kardorff pozostawiła po sobie wyłącznie wspomniane na wstępie dzienniki, jej postać nigdy nie stała w centrum zainteresowania badaczy, z tego powodu nie istnieje biografia dziennikarki, która umożliwiłaby bliższe poznanie jej osoby i w krytyczny sposób odniosłaby się do spisanej przez nią relacji. Nieliczne wzmianki na temat kobiety odnaleźć można w pracach poświęconych prasie i dziennikarstwu w Trzeciej Rzeszy 5 . W przypadku Margret Boveri sytuacja wygląda natomiast zupełnie inaczej - napisała ona nie tylko wspomnienia z ostatnich miesięcy wojny, ale także m.in. autobiografię $e^{6}$ w której przedstawiła historię swojej osoby od dzieciństwa do 1940 r., oraz książkę poświęconą „Berliner Tageblatt”", czyli gazecie, w której pracowała. W 2005 r. ukazała się biografia dziennikarki autorstwa Heike B. Görtemakera ${ }^{8}$.

Starsza z kobiet, Margret Boveri, przyszła na świat w Würzburgu jako jedyne dziecko pary biologów - Theodora Boveri oraz Marcelli z d. O’Grady. W związku z pochodzeniem matki, której rodzina przeprowadziła się z Irlandii do Stanów Zjednoczonych, Margret od najmłodszych lat odbywała z rodzicami podróże do USA, biegle mówiła zarówno po niemiecku, jak i angielsku. Praca Boverich wymagała od nich także podróży, m.in. do Włoch, z tego powodu znała również język włoski.

\footnotetext{
${ }^{5}$ M.in. N. FreI, J. SChmitZ, Journalismus im Dritten Reich, München 1999.

${ }^{6}$ M. BOVERI, Die Verzweigungen. Eine Autobiographie, München 1977.

7 IDEM, Wir lügen alle. Eine Hauptstadtzeitung unter Hitler, Breisegau 1965.

${ }^{8}$ H.B. GörteMAKER, Ein deutsches Leben. Die Geschichte der Margret Boveri, München 2005.
} 
Naukę Boveri pobierała głownie u prywatnych nauczycieli. Wpływ na to miały nie tylko podróże badawcze rodziców, ale także jej pochodzenie. W autobiografii napisała, że dzieci w wieku szkolnym formowane były w grupy i uczestniczyły w prywatnych lekcjach, by, zdaniem starszych, nie miały do czynienia z „gorszymi” dziećmi (tj. najprawdopodobniej pochodzącymi z rodzin nieinteligenckich - przyp. P.F.-Ch.). Lekcje przyrody odbywały się pod czujnym okiem Marcelli Boveri'. W roku 1920 Boveri rozpoczęła w Berlinie studia z zakresu filologii angielskiej, germańskiej oraz historii. W centrum jej zainteresowań od początku znajdowały się stosunki międzynarodowe ${ }^{10}$.

Pierwsze próby pisarskie Boveri podjęła przed dojściem do władzy narodowych socjalistów. Jej pierwszy felieton, dotyczący podróży samochodowej z Monachium do Neapolu został opublikowany w Frankfurter Zeitung w 1933 r. Za tekst autorka otrzymała wynagrodzenie w wysokości 350 marek. Miała także za sobą bardziej poważne próby pisarskie - w 1931 r. ukazała się jej monografia poświęcona Wilhelmowi Roentgenowi, który po śmierci ojca w 1915 r. pełnił funkcję jej mentalnego opiekuna ${ }^{11}$.

Swoją pierwszą pracę podjęła w „Berliner Tageblatt”. Początek jej pracy zawodowej zbiegł się w czasie z wprowadzanymi przez narodowych socjalistów obostrzeniami dotyczącymi gazet o charakterze liberalnym, socjaldemokratycznym i komunistycznym. Na podstawie wprowadzanych ustaw dotychczasowe etaty utraciło także wielu dziennikarzy pochodzenia żydowskiego.

Margret Boveri w swoich wspomnieniach określała siebie jako osobę o poglądach narodowych, nietolerującą polityki narodowych socjalistów. Kobieta w spisanej przez siebie autobiografii przyznała, że przed rokiem $1933 \mathrm{w}$ wyborach do Reichstagu opowiadała się po stronie socjaldemokracji, natomiast w tych np. do Landtagu głosowała na komunistów ${ }^{12}$. Nietrudno zauważyć, że w zachodzących zmianach dostrzegała dla siebie szansę na zdobycie etatu. Rynek wydawniczy i dziennikarski był zdominowany przez mężczyzn, wyjątkowe było także jak na tamte czasy jej zainteresowanie polityką zagraniczną. Obecnie nie ma dowodów na to, że Boveri była w partii lub wykazywała szczególne zaangażowanie w nazistowską politykę. Wraz z wybuchem wojny rozpoczęła pracę jako korespondentka „Frankfurter Zeitung”, pracując m.in. w Szwecji i w Stanach

\footnotetext{
9 M. BOVERI, Die Verzweigung..., s. 7-14.

${ }^{10}$ H.B. GÖRTEMAKER, op. cit., s. 30.

${ }_{11}$ M. BOVERI, Die Verzweigung..., s. 189.

${ }^{12}$ Ibidem, s. 210.
} 
Zjednoczonych. W drugiej połowie 1943 r. pracowała w Lizbonie. Po zamknięciu przez narodowych socjalistów jej dotychczasowego miejsca pracy powróciła do Niemiec, gdzie pisała m.in. do „Das Reich” oraz „Atlantis”.

Ursula von Kardorff przyszła na świat w Berlinie w 1911 r. w rodzinie, którą określiła mianem „solidnie mieszczańskiej, gdyby nie łagodząca okoliczność, że rodzice nie posiadali żadnego majątku i że oboje byli arystokratami" ${ }^{\prime 3}$. Ojciec dziennikarki był profesorem berlińskiej Akademii Sztuki, matka posiadała natomiast własne atelier rzemiosła artystycznego. Jak sama przyznała, jej rodzice wykazywali odmienny stosunek do rządów narodowych socjalistów. Matka dziennikarki długo było podatna na ich wpływy, dodatkowo żony prominentnych nazistów były jej częstymi klientkami. Podejście kobiety do narodowego socjalizmu zmieniło się w 1943 r., po śmierci syna na froncie wschodnim. Ojciec von Kardorff był natomiast od samego początku przeciwnikiem reżimu, z tego też powodu został w 1934 r. „przeniesiony” na emeryturę. Sama Kardorff miała początkowo ambiwalentny i pozbawiony głębszej refleksji stosunek do rządów nazistów. Z czasem, obserwując, jakie zmiany zachodzą w państwie, jej postawa stawała się coraz bardziej krytyczna. W czasie wojny utrzymywała także kontakty z opozycjonistami, w tym z osobami zaangażowanymi w spisek 20 lipca ${ }^{14}$.

Edukacja Ursuli von Kardorff nie różniła się od typowego wykształcenia mieszczańskich kobiet - ukończyła ona Szkołę Handlową, w której uczyła się stenografii oraz maszynopisania. W 1937 r. rozpoczęła pracę na stanowisku sekretarki ${ }^{15}$. W międzyczasie podejmowała już pierwsze próby pisarskie, kilka z jej artykułów ukazało się w „Deutsche Allgemeine Zeitung”, gdzie chciała pracować. Aby było to możliwe, musiała zdać egzamin kwalifikacyjny, na którym kandydaci byli przepytywani m.in $\mathrm{z}$ wiedzy na temat historii ruchu nazistowskiego. Podczas egzaminu Kardorff była jedyną osobą niezapisaną do partii, $\mathrm{z}$ tego powodu egzaminator, przewodniczący zrzeszenia prasowego, miał do niej negatywne nastawienia. Pytania, które jej zadano, dotyczyły np. przemów Hitlera podczas konkretnych wystąpień czy ustaw przeciw socjalistom stworzonych jeszcze w czasach Bismarcka ${ }^{16}$. W związku z tym, że wychowała się, dorastała i pracowała w Berlinie, była świadkiem wydarzeń zachodzących w mieście od początku wojny.

\footnotetext{
13 U. VON KARDORFF, op. cit., s. 221.

14 Ibidem, s. 223-223.

15 Ibidem, s. 227.

16 Ibidem, s. 228-229.
} 


\section{Sytuacja na froncie w roku 1945 oraz jej wpływ na nastroje w Niemczech}

Sytuacja wojsk niemieckich na froncie zaczęła się drastycznie pogarszać od chwili klęski pod Stalingradem. Śmierć wielu żołnierzy niewątpliwie wpłynęła na nastroje niemieckich obywateli - choć niektórzy z nich widzieli w poległych ofiary walki za ojczyznę, inni zaczęli być coraz bardziej świadomi zbliżającej się klęski ${ }^{17}$. Defetyzm narodu niemieckiego próbowano złagodzić treściami propagandowymi, w których zagrzewano do walki ${ }^{18}$.

Pogorszająca się sytuacja na froncie wschodnim nie była jedynym problemem, z którym musieli borykać się wojskowi oraz nazistowscy dygnitarze - wydarzenia na froncie zachodnim również przybierały niekorzystny obrót dla wojsk niemieckich. Mimo względnego sukcesu III Rzeszy, jakim była wygrana w bitwie pod Arnhem, niepowodzenia odniesione podczas bitwy o Skaldę, a następnie klęska niemieckiej ofensywy w Ardenach dawały coraz mniej nadziei na wygranie wojny ${ }^{19}$.

Armia Czerwona, stacjonująca na początku stycznia 1945 r. nad Wisłą, w ciągu trzech tygodni zajęła Prusy Wschodnie i kontynuowała ofensywę w kierunku Berlina. Relacje uciekinierów na temat zachowania żołnierzy sowieckich względem ludności cywilnej wywoływały wśród Niemców lęk oraz poruszenie. Niepokojące wieści docierały także od uchodźców z terenów Śląska - podobnie jak w przypadku Prus, cywile mówili o rabunkach, morderstwach i gwałtach dokonywanych przez Sowietów na Niemcach ${ }^{20}$. Na podstawie innych materialów źródłowych można zauważyć, że o ile mieszkańcy Niemiec odczuwali strach przed Sowietami, brak w tych relacjach informacji o podobnych odczuciach względem żołnierzy amerykańskich czy brytyjskich.

Sytuacji nie poprawiały także przeprowadzane przez aliantów naloty. Skutkiem tychże było nie tylko zniszczenie miast, ale także śmierć ludności cywilnej. Do jednego z największych i najtragiczniejszych ataków lotniczych zaliczyć można z pewnością bombardowanie Drezna mające miejsce w nocy z 13 na 14 lutego. Bomby przyczyniły się nie tylko do zniszczenia zabudowań - na skutek

\footnotetext{
17 S.G. FritZ, Ostkrieg. Front wschodni: wojna na wyniszczenie, Oświęcim 2018, s. 417-418.

18 R.J. Evans, op. cit., s. 616-617.

19 T. THACKER, op. cit., s. 54-64.

20 A. Beevor, Druga wojna światowa, Kraków 2013, s. 860-863.
} 
burzy ogniowej spaleniu uległo ok. $18 \mathrm{~km}^{2}$ miasta; nie sposób także ustalić konkretnej liczby ofiar, które zostały pogrzebane żywcem w zawalonych budynkach, lub tych, którzy ucierpieli na skutek pożarów ${ }^{21}$.

Największe obawy, zarówno wśród ludności, jak i nazistowskiego rządu, wzbudzała jednak zbliżająca się nieustannie w kierunku Berlina Armia Czerwona. Ofensywa na stolicę Trzeciej Rzeszy zaplanowana została na 16 kwietnia, zakończyć się miała 6 dni później - 22 kwietnia obchodzono bowiem urodziny Lenina ${ }^{22}$. Rozpoczęta planowo operacja zakończyła się później, jednak do 25 kwietnia wojska 1. i 2. Frontu Białoruskiego oraz 1. Frontu Ukraińskiego otoczyły Berlin, pozbawiając tym samym rząd Adolfa Hitlera nadziei na wygranie wojny ${ }^{23}$.

\section{Ostatnie miesiące wojny oczami dziennikarek}

W Berlinie Margret Boveri mieszkała początkowo w Charlottenburger-Wundstarsse, jednak po zbombardowaniu mieszkania przeniosła się na Thielalle w dzielnicy Dahlem, Ursula von Kardorff mieszkała natomiast przy Placu Paryskim w dzielnicy Tiergarten. Możliwość obserwowania nastrojów w dwóch oddalonych od siebie obszarów pozwala z pewnością dokładniej opisać skalę zniszczeń, których doświadczyło miasto.

W relacji Ursuli von Kardorff początek nowego roku upłynął pod znakiem nalotu, który dokonał zniszczeń w postaci powybijanych szyb. W noc sylwestrową odwiedziła ją grupa przyjaciół, jednak, jak napisała kobieta: „staliśmy z kieliszkami w dłoniach, nie śmiejąc wznieść toastu”24.

Po niespełna dwutygodniowej nieobecności spowodowanej chorobą i śmiercią ojca dziennikarka powróciła do Berlina, opisując go mianem „oszalałego i rozhisteryzowanego". Nie była świadkiem zniszczeń, jakich dokonała bomba burząca, która spadła blisko jej mieszkania, jednak o skutkach ataku dowiedziała się od przyjaciół ${ }^{25}$.

\footnotetext{
${ }^{21}$ M. GilberT, Druga wojna światowa, Warszawa 2011, s. 764-765.

22 A. BeEvor, Berlin..., s. 146.

${ }^{23}$ S.G. FriTZ, op. cit., s. 438-441.

${ }^{24}$ U. vON KardorfF, op. cit., s. 157.

${ }^{25}$ Ibidem, s. 160.
} 
Informacje o nieustannych bombardowaniach można odnaleźć w obu relacjach. Działania aliantów doprowadzały nie tylko do zniszczeń w infrastrukturze i śmierci ludności cywilnej, ale także utrudniały normalne funkcjonowanie. W relacji z 3 i 4 lutego Margret Boveri napisała o problemach w dostawach wody. Ilość, jaką udało jej się uzyskać, była niewielka, wystarczyła do mycia i gotowania na jeden dzień. Większość mieszkańców zmuszona była korzystać ze studni, jednak w przypadku zamieszkiwania wyższych pięter (w przypadku Boveri było to 4. piętro kamienicy), pozyskiwanie wody oraz wnoszenie jej na górę było problematyczne ${ }^{26}$. Niestety, w źródłach nie pojawiają się informacje o jakości wody z tego ujęcia.

Wspomniana data - 3 lutego - jest bardzo ważna w kontekście przebiegu działań wojennych. Tego dnia miało miejsce jedno z poważniejszych bombardowań Berlina od początku wojny. Jest ono potwierdzone nie tylko w relacjach naocznych świadków, ale także w literaturze przedmiotu. Nalot przeprowadzony przez amerykańskie samoloty doprowadził do śmierci ponad 3000 ludzi oraz ogromnych zniszczeń, któremu uległy m.in. redakcje gazet ${ }^{27}$. Boveri napisała wyłącznie o bombie oraz zniszczeniach w jej najbliższej okolicy, nie wspomniała natomiast o sile ataku oraz tym, że ucierpiały wtedy m.in. budynki redakcji. Należy założyć, że w czasie ogólnej dezinformacji i problemów komunikacyjnych nie miała świadomości skali zniszczeń ${ }^{28}$. Więcej na ten temat można natomiast odnaleźć w relacji Ursuli von Kardorff, która nazwała bombardowanie „najcięższym nalotem na śródmieście"29. Pamiętać należy, że mieszkała ona niemal w centrum Berlina, Boveri natomiast dalej, dlatego też druga z kobiet mogła nie mieć świadomości, jak poważnych zniszczeń dokonali Amerykanie. Po odwołaniu alarmu Kardorff wybrała się wraz ze znajomym na rozeznanie w terenie, gdzie zobaczyła zniszczony budynek swojej dotychczasowej pracy. Według przedstawionych przez nią informacji, żaden z pracowników gazety nie zginą ${ }^{30}$.

W tym czasie Kardorff rozważała już opuszczenie Berlina. We wpisie z dnia 9 lutego napisała, że dyrektor wydawnictwa przyjął jej wypowiedzenie - choć zgodnie z panującym wówczas prawem nie powinien tego robić. Kobieta

\footnotetext{
${ }^{26}$ M. Boveri, Tage..., s. 33-35.

27 A. BeEvor, Berlin..., s. 67.

${ }^{28}$ O fakcie zniszczenia siedziby „Das Reich” napisała 6 lutego.

29 U. vON KARDORFF, op. cit., s. 163.

${ }^{30}$ Ibidem, s. 164.
} 
zaznaczyła także, że redakcja gazety ma zostać wkrótce czasowo zamknięta ${ }^{31}$. Potwierdzenia tych informacji nie można jednak odnaleźć w relacji Margret Boveri - niewiele napisała ona na temat wykonywania swoich obowiązków zawodowych, informacja taka pojawia się zaledwie raz - w zapisku z 6 lutego - w którym to dziennikarka napisała o podróży do redakcji (niezwykle utrudnionej ze względu na panujące w mieście zniszczenia) ${ }^{32}$. Zakładać należy, że wykonywanie obowiązków zawodowych w realiach wojny było trudne. Potwierdzać mogą to słowa Ursuli von Kardorff, która napisała, że „z powodu alarmów lotniczych nie chodzi się spać o normalnej porze, więc wstaje się potem możliwie jak najpóźniej. O prawdziwej pracy nie ma już mowy" ${ }^{33}$. Obecnie trudno jest ustalić, nad jakimi konkretnie tekstami pracowały kobiety w ostatnich miesiącach wojny - jedną wzmiankę na ten temat można odnaleźć u Boveri, która, zgodnie $\mathrm{z}$ relacją, $\mathrm{w}$ dniach poprzedzających zakończenie konfliktu pisała artykuł poświęcony śmierci prezydenta Stanów Zjednoczonych - Franklina Delano Roosevelta ${ }^{34}$. Nie wiadomo jednak, czy artykuł ten napisała w domu, czy też w redakcji oraz kiedy i w jakiej formie się on ukazał.

W obu relacjach, choć w różnym stopniu, zauważyć można opis stosunków międzyludzkich. Obecność przyjaciół lub sąsiadów pozwalała znieść trudny wojenny czas. W niektórych przypadkach chodziło po prostu o czyjąś obecność, $\mathrm{w}$ innych - o pomoc w uzyskaniu pożywienia lub schronienia. Wydaje się, że Ursula von Kardorff, która od lat młodości przyzwyczajona była do przyjęć i spotkań towarzyskich, szczególnie trudno znosiła samotność. Utrzymywanie kontaktów towarzyskich umożliwiło jej chociażby ucieczkę z Berlina. Jak sama pisała w swoim dzienniku: „Nie jestem już teraz nigdy sama. Ludzie zbijają się w gromady jak stado bydła przed burzą, nikt nie może znieść samotności. Rozmowy obracają się tylko wokół fałszywych paszportów, zaświadczeń, podróży służbowych, dowodów osobistych cudzoziemskich robotników, świadectw lekarskich" ${ }^{35}$. Kobieta nie wyjaśniła jednak, kto w szczególności zainteresowany był fałszywymi dokumentami. Biorąc pod uwagę specyfikę źródła, logiczne się wydaje, że autorka nie podawała danych swoich znajomych, którzy rozważali

\footnotetext{
${ }^{31}$ Ibidem, s. 165-166.

32 M. BOVERI, Tage..., s. 37.

33 U. vON KARDORFF, op. cit., s. 165.

${ }^{34}$ M. BOVERI, op. cit., s. 55.

35 U. vON KARDORFF, op. cit., s. 164.
} 
wyjazd ze stolicy Niemiec. Można przypuszczać, że chodziło albo o mężczyzn starających się uniknąć powołania do Volkssturmu ${ }^{36}$, albo o osoby, które chciały uniknąć spotkania z wojskami sowieckimi.

W przypadku Margret Boveri kwestia kontaktów z innymi ludźmi nie została aż tak szczegółowo opisana. W jej relacji przedstawiona została oczywiście kwestia chociażby stosunków sąsiedzkich - wzajemna pomoc w zdobywaniu jedzenia, przy zdobywaniu materiałów lub pozyskiwaniu informacji na temat obecnej sytuacji. Jeśli tylko istniała taka możliwość, starała się utrzymywać kontakt telefoniczny z mieszkającymi dalej przyjaciółmi, jednak w związku ze zniszczeniami, nie zawsze było to możliwe ${ }^{37}$.

Marget Boveri, w przeciwieństwie do Ursuli von Kardorff wiele miejsca w swoich zapiskach poświęciła kwestii wyżywienia. Podaje ona przykłady przyrządzanych potraw, jak np. sałatki ziemniaczanej z suszoną kiełbasą, podaną z ersatzem kawy i sucharami. Chleb - najbardziej poszukiwany produkt spożywczy - dostępny był w małych ilościach. Jak napisała kobieta, z tego, który otrzymała od przyjaciół, jadła dziennie 2-3 kromki, by starczył na dłużej. Alternatywę stanowiły natomiast bułki, które były jednak gorszej jakości ${ }^{38}$. Po analizie źródeł można zauważyć, że posiłki, które wówczas spożywano, były raczej proste i łatwe w przygotowaniu. Starano się, chociażby poprzez dodawanie tłuszczu, wzbogacić je i dodać im większej wartości kalorycznej. Niestety, brak w źródłach dokładnych informacji na temat sposobu pozyskiwania żywności - jak wiadomo, w czasie wojny produkty spożywcze i przemysłowe były racjonowane w systemie kartkowym, a każdego mieszkańca Niemiec, ze względu na wykonywany zawód, obejmował inny przydział. Na początku wojny każdy dorosły mógł otrzymać miesięcznie ok. $10 \mathrm{~kg}$ chleba, 1,4 kg tłuszczu, 2,4 kg mięsa. Wraz z rozwojem działań wojennych racje zaczęły maleć, a w ostatnich miesiącach wojny ich wielkość była niezwykle niska - w styczniu 1945 przydział miesięczny wynosił $10,5 \mathrm{~kg}$, natomiast w kwietniu tego roku można było kupić już tylko 3,6 kg. Podobnie było także z mięsem (550 g) czy tłuszczem (spadek z 875 do $325 \mathrm{~g})^{39}$.

${ }^{36}$ Do Volkssturmu werbowano chłopców i mężczyzn w przedziale wiekowym od 16 do 60 lat - por. T. THACKER, op. cit., s. 11.

${ }^{37}$ M. BOVERI, op. cit., s. 64.

38 Ibidem, s. 51-52.

39 R.J. Evans, op. cit., s. 389. 
W związku z brakiem możliwości normalnego zaopatrzenia się w artykuły pierwszej potrzeby, niemal od początku wojny nie tylko w nazistowskich Niemczech, ale także na terenach okupowanych przez Trzecią Rzeszę, prężnie rozwijał się czarny rynek. Autorki źródeł nie piszą co prawda o tym, czy z niego korzystały, niemniej na uwagę zasługuje opis sytuacji, dość powszechnej w czasie wojny, przedstawionej przez Margret Boveri. Dziennikarka zauważyła kobietę idącą z kawałkiem mięsa, zapytała więc, w jaki sposób udało jej się je zdobyć. Okazało się, że na ulicy leżało ciało padłego konia. Boveri udała się we wskazane miejsce, gdzie faktycznie znajdowała się „połowa jeszcze ciepłego” zwierzęcia. Zebrani wokół ludzie próbowali uzyskać dla siebie choć fragment mięsa - Boveri wykroiła z konia ćwiartkę płuca oraz udziec. Zgodnie z przedstawioną przez kobietę relacją, płuco przygotowała z cebulą, tymiankiem i zasmażką, a z powstałej masy zrobiła ersatz kaszanki (niem. Lungenblutwurst) ${ }^{40}$.

Przygotowywanie posiłków było także utrudnione w związku z przerwami $\mathrm{w}$ dostawie gazu. Boveri próbowała poradzić sobie z tym problemem poprzez stworzenie prowizorycznej kuchenki. Jak sama jednak napisała, zbudowanie jej było większym wyzwaniem, niż mogłoby się wydawać - każdego dnia musiała przedzierać się między gruzami, by znaleźć odpowiedni kamień, na którym mogłaby postawić kratkę, pełniącą funkcję rusztu ${ }^{41}$.

W obu relacjach zauważalna jest także obawa przed żołnierzami Armii Czerwonej. Choć obie dziennikarki nie doświadczyły bezpośrednio przemocy z rąk wrogiej armii, docierały do nich informacje od znajomych, którzy byli świadkami zachowań sowieckich żołnierzy bądź też usłyszeli o zachowaniu armii od innych osób. Kobiety, wykluczając informacje o bombardowaniach, raczej mało pisały o sytuacji na froncie zachodnim - wyjątek stanowi relacja Ursuli von Kardorff po wyjeździe z Berlina, która odczuwała jeszcze większy strach przed nieprzyjacielskimi samolotami i zniszczeniami, jakich one dokonywały, niż w stolicy. Kilkukrotnie w swoim dzienniku pisała o żalu, który towarzyszył jej po opuszczeniu rodzinnego miasta ${ }^{42}$. Choć obie kobiety pracowały w prasie, trudno było im uwierzyć w wiadomości przedstawiane w gazetach - Ursula von Kardorff była początkowo przekonana, że negatywny wizerunek Armii Czerwonej oraz opis dokonywanych przez nią zbrodni wynikał z działań ministra propagandy

\footnotetext{
${ }^{40}$ M. BOVERI, op. cit., s. 97-98.

${ }^{41}$ Ibidem, s. 69, 71.

${ }^{42}$ U. vON KARDORFF, op. cit., s. 170-171.
} 
Josepha Goebbelsa. Dopiero relacje znajomych i przyjaciół przybywających z terenów Prus Wschodnich lub Śląska uzmysłowiły jej, że nie wszystko, co można znaleźć w prasie, jest partyjną manipulacją ${ }^{43}$. Margret Boveri napisała natomiast o tym, że w omawianym okresie praktycznie w ogóle nie czytała gazet, ponieważ za dużo w nich było informacji na temat przemocy i zniszczeń - doświadczała ich każdego dnia, dlatego też nie chciała jeszcze o nich czytać ${ }^{44}$.

Należy także napisać o dwóch innych, ważnych z perspektywy mieszkańców Niemiec wydarzeniach - pierwszym z nich były mające miejsce 20 kwietnia 56. urodziny Adolfa Hitlera, drugim - jego śmierć kilka dni później. Od początku istnienia Trzeciej Rzeszy urodziny Führera były dniem wyjątkowym dla Niemiec - poza przyjęciami w Ministerstwie dla zaufanych funkcjonariuszy oraz innych wyjątkowych gości, odbywały się wówczas parady wojskowe, a w całym mieście rozwieszone były flagi. W trakcie obchodów 50. urodzin Hitlera miała miejsce uroczystość państwowa, na której przemawiali najważniejsi nazistowscy dostojnicy, a cała ceremonia transmitowana była w radiu ${ }^{45}$. W warunkach wojennych zorganizowanie hucznych uroczystości było niemożliwie, w szczególności w 1945 r., nie tylko ze względu na wspomniane wcześniej bombardowanie miasta dokonane przez lotnictwo amerykańskie i brytyjskie, ale także ze względu na toczącą się od czterech dni operację berlińską ${ }^{46}$.

Margret Boveri nie zapisała w swojej relacji żadnych przemyśleń o tym dniu - można zakładać, że albo było to dla niej nieistotne, albo w czasie bombardowań oraz trudnej sytuacji zaopatrzeniowej skupiła się przede wszystkim na przetrwaniu tego okresu. Ursula von Kardorff, nieprzebywająca już wówczas w Berlinie, napisała natomiast o nadawanej w radiu mowie Goebbelsa. Słowa ministra propagandy wywarły na kobiecie duże wrażenie - zastanawiała się, dlaczego w chwili zbliżającej się klęski stara się on wykrzesać w narodzie ducha walki i minimalizować zagrożenie, jakie stwarzały zarówno oddziały aliantów, jak i znajdująca się w okolicach Berlina Armia Czerwona ${ }^{47}$.

${ }^{43}$ Ibidem, s. 163.

${ }_{44}$ M. BOVERI, op. cit., s. 74.

45 Powyższy opis pochodzi z zapisków z dzienników Josepha Goebbelsa - vide: J. GoebBbeLS, Dzienniki, t. 1: 1923-1939, Warszawa 2016, s. 296, 380, 447, 559-560.

46 P. Longerich, Hitler. Biografia, Warszawa 2017, s. 1182-1183.

${ }^{47}$ U. vON KARDORFF, op. cit., s. 177. 
Sytuacja po śmierci przywódcy Trzeciej Rzeszy także została przedstawiona przez kobiety w odmienny sposób. Boveri napisała jedynie o tym, że „mówiło się" o śmierci Hitlera oraz o tym, że dowództwo miał przejąć po nim admirał Karl Dönitz ${ }^{48}$. Częściowo jest to prawdą, ponieważ krótko przed swoją śmiercią w spisanym testamencie Hitler przekazał władzę Dönitzowi, który miał zostać prezydentem Rzeszy, stanowisko kanclerza przypadło natomiast Josephowi Goebbelsowi ${ }^{49}$. Brak pewności i pełnego obrazu sytuacji można przypisać dezinformacji, która panowała w mieście.

Ursula von Kardorff o śmierci Führera dowiedziała się w nocnej audycji radiowej. Podobnie jak Boveri napisała o Dönitzu jako następcy Hitlera, nie wspomniała natomiast o Goebbelsie. Nie wiadomo niestety, z jakiego źródła pochodziła ta informacja. Śmierć Hitlera wywołała w kobiecie uczucie ulgi i wzruszenia, odczuwała jednak wielki smutek, myśląc o wszystkich poległych bliskich i przyjaciołach.

\section{Podsumowanie}

Impulsem do napisania powyższego artykułu była próba odpowiedzi na pytanie, czy kobiety związane $\mathrm{z}$ dziennikarstwem - a tym samym zorientowane w wydarzeniach wewnętrznych i międzynarodowych, często poruszające w swoich artykułach kwestie społeczne - postrzegały sytuację w ostatnich miesiącach II wojny światowej inaczej niż niezwiązani z tym zawodem mieszkańcy III Rzeszy. Na postawie przedstawionej analizy źródeł można zauważyć, że w kontekście omawianych wydarzeń wykonywanie zawodu dziennikarki nie wpływało w znaczący sposób na postrzeganie ówczesnych realiów. Zarówno Margret Boveri, jak i Ursula von Kardorff musiały mierzyć się z podobnymi problemami co inni obywatele, co więcej, wykonywanie obowiązków zawodowych było utrudnione ze względu na liczne naloty, w związku z czym konieczne było niekiedy wielogodzinne przebywanie w schronie. Sytuacji nie ułatwiał także fakt zniszczeń budynków administracyjnych oraz utrudnienia w komunikacji miejskiej - w tym ostatnim przypadku podróż z miejsca zamieszkania do miejsca pracy mogła trwać wiele godzin.

\footnotetext{
48 M. BOVERI, op. cit., s. 97.

49 P. LONGERICH, op. cit., s. 1186.
} 
Zróżnicowane doświadczenia życiowe oraz charaktery obu kobiet wpływały jednak na odmienne postrzeganie sytuacji społeczno-politycznej w ostatnich miesiącach wojny. Nie można wykluczyć, że von Kardorff odbierała zniszczenie miasta w sposób bardziej emocjonalny niż Boveri - dla pierwszej z nich było to miasto, w którym się wychowała i dorastała, druga trafiła do niego na progu swojej dorosłości. W obu źródłach zauważyć można, że ich autorki skupiły się głównie na opisywaniu problemów społecznych, niewiele można natomiast znaleźć informacji na temat polityki czy relacji z frontu.

\section{BIBLIOGRAFIA}

\section{Źródła drukowane}

Boveri M., Die Verzweigungen. Eine Autobiographie, München 1977.

Boveri M., Tage des Überlebens. Berlin 1945, München 1968.

Goebbels J., Dzienniki, t. 1: 1923-1939, Warszawa 2016.

Kardorff von U., Może to po raz ostatni, Warszawa 1992.

\section{Opracowania}

Beevor A., Berlin. Upadek 1945, Warszawa 2002.

Beevor A., Druga wojna światowa, Kraków 2013.

Evans R.J., Wojna Trzeciej Rzeszy, Oświęcim 2017.

Fritz S.G., Ostkrieg, Front wschodni: wojna na wyniszczenie, Oświęcim 2018.

Gilbert M., Druga wojna światowa, Warszawa 2011.

Görtemaker H.B., Ein deutsches Leben. Die Geschichte der Margret Boveri, München 2005.

Longerich P., Hitler. Biografia, Warszawa 2017.

Thacker T., Koniec Trzeciej Rzeszy, Warszawa 2010. 


\title{
Paulina Fronczak-Chruściel
}

\section{THE FALL OF BERLIN THROUGH THE EYES OF WOMEN. THE CASE OF MARGRET BOVERI AND URSULA VON KARDORFF}

\begin{abstract}
Summary. The aim of this article is to present the situation in Berlin in the last months of the Second World War from a perspective of two journalists - Margret Boveri and Ursula von Kardorff. Comparative analysis of two sources should present varied problems of citizens of Third Reich in the final phase of the war - for example - problems with provisioning, power and water outage or difficulties with commuting by public transport. In a context of the above considerations no less important were descriptions of German citizens panic, caused by numerous bombardments and by soldiers of Red Army. The proper considerations were preceded by short characteristics of both authors, including for example: descent, education, career path or approach to politics. Analysis of this information helps to understand both women attitude not only to the situation in Berlin, but also to broadly defined warfare. In order to systemize the narration in the article was presented a short description of the situation at the both fronts in the last months of the war.
\end{abstract}

Keywords: woman, Berlin, journalist, Third Reich, World War II, diaries 
